\title{
Problems with Separation in an Identical Twin
}

Henry A. Doenlen, MD

Thomas Jefferson University Hospital

Follow this and additional works at: https://jdc.jefferson.edu/jeffjpsychiatry

Part of the Psychiatry Commons

Let us know how access to this document benefits you

\section{Recommended Citation}

Doenlen, MD, Henry A. (1985) "Problems with Separation in an Identical Twin," Jefferson Journal of Psychiatry. Vol. 3 : Iss. 1 , Article 12.

DOI: https://doi.org/10.29046/JJP.003.1.008

Available at: https://jdc.jefferson.edu/jeffjpsychiatry/vol3/iss1/12

This Article is brought to you for free and open access by the Jefferson Digital Commons. The Jefferson Digital Commons is a service of Thomas Jefferson University's Center for Teaching and Learning (CTL). The Commons is a showcase for Jefferson books and journals, peer-reviewed scholarly publications, unique historical collections from the University archives, and teaching tools. The Jefferson Digital Commons allows researchers and interested readers anywhere in the world to learn about and keep up to date with Jefferson scholarship. This article has been accepted for inclusion in Jefferson Journal of Psychiatry by an authorized administrator of the Jefferson Digital Commons. For more information, please contact: JeffersonDigitalCommons@jefferson.edu. 


\title{
PROBLEMS WITH SEPARATION IN AN IDENTICAL TWIN
}

\author{
HENRY A. DOENLEN, M.D.
}

The author wishes to express his appreciation to Theodore Cohen, M.D., and Thomas Fisher, M.D., for their help in understanding this patient.

\section{INTRODUCTION}

During residency we learn to apply the theories of development to understand and help our patients. These theories are based upon the relationship between a single child and his parents as he struggles to separate and individuate. Identical twins have special problems in that not only do they have to separate from their parents, but also from each other.

\section{CASE REPORT}

The patient is a nine-year-old female twin with an initial chief complaint of pulling out her upper eyelashes. This had been occurring intermittently for six months at various times during the day. The parents had tried to deal with the problem by talking, bribing, and punishing the patient. Once her mother put mittens on her hands in an effort to prevent the eyelash pulling at night. The next morning the patient reported that a voice told her to take off the mittens. The patient performed above average work in school, but worried about her homework being correct and argued with her parents when they tried to help her with it. Past history indicated that she lost weight shortly after birth and remained in the hospital for one weeek after her sister went home.

This patient has been followed in twice a week therapy for the past year. Her parents have been seeing a separate therapist weekly. Her parents felt that she pulled out her eyelashes to make her look different from her identical twin sister, but the patient did not agree with this. Initially she could not identify any feeling or thought that preceeded or accompanied the eyelash pulling. She was particularly vague about the voice, but said it reminded her of a bedtime imagination when she was four; in this imagination she saw a face in the window that could take her away. At the time of the twin's ninth birthday, the patient wrote on a piece of paper the wish that her sister would die. She believed that the wish would come true and became very anxious, resulting in her pulling out all of her upper eyelashes. In the next several months, she pulled out her eyelashes on days when she had been angry at her sister and wished she would die. The anger was usually due to her sister not wanting to play with the patient.

Dr. Doenlen is chief senior child fellow. 
The patient was also able to recall that at age three she and her twin could speak a language that only they "and the cat could understand." She also told a story of "missing" her sister after birth while she remained in the hospital.

As this information was repeated several times and in several ways, it became clear that one of the patient's conflicts surrounded her wish to regain the close, interdependent relationship she had with her twin when she was younger. This opposed her desire to be recognized as a unique individual by her family and friends. This was acted out in the transference as the patient at times became frustrated at my not understanding something she was describing in a vague manner. During therapy she was very interested in competing with board games. She stated she and her sister spent much time playing games and that each had different games they played well. She also felt proud that she did better in school than her twin, but mentioned that it was only by "one or two A's" and that her mother would not allow them to compare school grades. From this it became clear that there were simultaneous wishes to compete and win over the twin sister, while wishing neither would be superior.

About six months after therapy began this conflict was described to the patient and she felt that she understood it. Subsequent fights with her sister offered an opportunity to review this interpretation. Within a few months the patient reported that she was rarely fighting with her sister and she was not pulling out her eyelashes. She eventually had her hair cut and this made her look different from her twin. She denied that she cut her hair for this reason, but complained that some of her classmates still confused her with her sister. The patient developed a new problem of biting her fingernails, even to the point where they hurt. The patient mentioned that her mother could not prevent her from pulling her eyelashes or biting her fingernails, insisting that the eyelashes and fingernails would grow back. The patient continues to ask her parents for help with homework, only to argue about their help. One aspect of asking for help was that it allowed her to get more attention from her parents than her sister.

Sessions with the parents revealed that there was a subtle struggle for control between the mother and the father. This struggle was often played through passive means, e.g., not completing work around the house. The parents denied feeling angry at each other.

The mother saw the patient as having a controlling and compulsive personality like her own mother (maternal grandmother), towards whom she felt angry. During the twins' development, the parents tried to differentiate them by dressing them in different colors, although they had similar clothes and hair of the same length.

\section{DISCUSSION}

In her review of previous case studies, Siemon (1) described three processes that can influence the ego development of twins. Two of these, twin interidentification and the twinning reaction, apply to this patient. Twin interidentification is the twins' defense against the pain of separation from their mother by increasing their intimacy with each other. With my patient, conflicts between the parents may have led to some depression in the mother with a subsequent decrease in her ability to nurture the twins. 
Furthermore, caring for twins is more physically, mentally, and economically stressful than caring for a single child; as a result, there is an increased incidence of child abuse with twins (2). Although child abuse has not occurred in this family, the heightened parental stress has lead to an even more intense interdependence between the twins.

The "twinning reaction" describes the sense of fusion between twins. My patient fondly remembers the time when she and her sister had their own special relationship with shared language and experiences. However, intense rivalry for individual attention existed within this intimacy. This patient showed the intensity of this conflict by pulling out her eyelashes when she wished her sister would die, while simultaneously fearing that her wish would come true. This conflict was also acted out on a daily basis by competing with her twin, but not allowing one to be superior.

Dibble and Cohen's longitudinal study of a group of families with twins (3) revealed that all of the parents reported some behavioral problems with twins and that twin development greatly depended on prior parental fantasies about them. In their study it was found that the twin with better newborn endowment seemed to cope better with stress than the less-endowed twin. My patient's perinatal physical problems may have led her to be more fussy and irritable than her sister. This reinforced her mother's fantasy that this child was like her own demanding mother. The parents tried to treat each of the twins equally (thus enhancing the twinning reaction), but the patient probably felt the influence of this fantasy through subtly expressed fears and anger. In response, my patient developed a greater need to be intimate with her sister. She also developed a conflictual and unconscious anger towards her mother which was acted out by intermittently taking on the role of the compulsive and demanding grandmother. The conflictual nature of this anger was shown by simultaneous disobedience towards her mother and mutilation of herself in the eyelash pulling.

Siemon, a twin herself, has also summarized the complications that twinship causes with intimacy (1). My patient has shown through the transference her expectation that the therapist will automatically understand her thoughts and feelings. One effect of psychotherapy is that this patient will understand that intimacy with others requires more communication than needed with her sister. She has used therapy to decrease her anxiety associated with the fantasy that her wishes could come true. One final benefit of therapy has been to allow an easier process of separation and individuation from her twin.

\section{REFERENCES}

1. Siemon M: The separation-individuation process in adult twins. Am J Psychother 34: $387-399,1980$

2. Robarge J, Reynolds Z, Groothuis J: Increased child abuse in families with twins. Res Nurs Hlth 5: 199-203, 1982

3. Dibble E, Cohen D: Personality development in identical twins. Psychanal Study Child 36: $45-70,1981$ 